RISMED 00125

\title{
Editorial
}

\section{Needles, AIDS, and lessons unheeded?}

In rendering medicine as safe as it can reasonably become, it is not sufficient to agree on standards; those standards also have to be met. That would be a truism if it were not for the fact that, once standards have been set and accepted, it is all too easy to believe that the goal has been achieved and that one can relax. The dangerous belief that lip-service to accepted standards is quite sufficient to do good emerges on too many fronts. Has the admirable Code of Marketing of Breast Milk Substitutes really been followed, or is it for some people no more than fine language? How many clinical experiments really do accord with the Declarations of Helsinki and Tokyo?

There is more than enough reason to put the same sort of question as regards the elementary principle that re-usable syringes and needles should be adequately disinfected, and that their disposable equivalents should never be reused. Surely, with AIDS and infectious hepatitis B in the front of every well-ordered medical mind, that is fairly elementary good sense?

Not, unhappily, everywhere. The latest reason to become very concerned is given by Prof. Luis Policarpo of Buenos Aires, who is waging a one-man campaign against the indifference which he believes he discerns in his very own country to precisely those principles. His is not the first expression of concern, but it is unusually well documented.

To begin at the beginning: where did the standard get such emphasis? The World Health Organization's cogent "Sterilization Alert" of 1987 was clear enough. "Unsterile injections can transmit infectious diseases such as hepatitis B and AIDS ... disposable syringes and needles should be used only if it can be assured that they will be destroyed after a single use..." and such conclusions were backed by a call to warn the public as well as the health services to be on the lookout for unsafe injection practices [1]. The W.H.O. report was backed by impressive research both before and after the date of its appearance [2-7], and there has been confirmation in plenty more recently.

If there was any residual belief that disposable syringes, which have fixed needles, could with proper sterilization be re-used, work in recent years should have displaced it. A disposable plastic syringe is made of a type of plastic (generally polypropylene) that will soften and distort at boiling temperatures or when placed in a steam sterilizer. Steam is also likely to remove the silicone lubricant which renders these low-cost products adequately functional and safe for use on one occasion only. There is no alternative way of effectively cleaning a disposable syringe that will guarantee its sterility; the original factory sterilization is by irradiation, but for a series of good reasons this is a one-time venture only, 
particularly since this process will not remove whatever materials have entered the needle or syringe during its original phase of use. As to disinfectants, these again are unlikely to remove residual material, and they may themselves attack or bind to the polypropylene of which the syringe is made or add a new and potentially dangerous residue. There are indeed such things as re-usable re-sterilizable plastic syringes, but they are in a class of their own, and much more akin to the glass product, both in price and quality; it is almost a pity that they exist, for their existence confuses the issue, but they have their uses.

The rule was thus simple and the standard well founded. How well was the standard accepted? To the informed medical profession it was evident good sense, but it was also widely recognized by policy makers and the public. To what extent public alertness helps to police practice is another matter. A patient receiving an injection from his doctor will hardly be inclined to express distrust in him to the extent of enquiring how assiduously he disinfects or discards his syringes and needles; nor will the patient in a Latin American country who is prone to call in for an injection at his neighbourhood pharmacy. Public and political alertness can, all the same, only do good.

But what standards really are maintained? One has evidence in plenty from some developing countries in Africa, as well as from Romania, that practice has been far from perfect, and that infection has continued down to the present to be disseminated in this way. Prof. Policarpo's case, which he presses with courage and conviction, is that Argentina is yet another example of a country where the rules which have been formally accepted for the last four years [8] need to be more fully respected and more rigidly enforced. He cites a document from the Congress itself, citing “... cases brought against private hospitals in this Federal Capital, where disposable syringes were repeatedly being used, although there had been attempts to sterilize them ... which places hundreds of unaware patients at risk." [9]. He has found himself involved as one of a series of experts in a judicial investigation of a case in which the Medical Director of a private hospital was prosecuted for washing disposable syringes with a non-medical detergent; that particular study showed that disposable syringes subjected to re-use were in a deplorable condition and contained foreign material. Prof. Policarpo has reason to believe that the practice is nevertheless becoming ever more widespread. In his view, as he has brought forcefully to the attention of the Minister of Health by letter, petition and telegram, lack of official action to enforce what are in fact accepted rules may be due to "indolence, indifference, negligence, corruption of a combination of several of these..." [10].

As in so many cases, the better a country arranges its affairs, the more diligent it may become at exposing the unacceptable; the end-result may be an unwarranted suggestion that things are a great deal worse within one's own frontiers than they are elsewhere, where there has been no diligent attempt to arrive at the truth. One therefore has no particular reason, from half a world away, to pillory Argentina; things may be a great deal worse in many other places, and some moves clearly have been made to put the situation to rights [11]. The accusations in Argentina - in part documented by firm evidence - are in the world view primarily 
important because they throw into profile the fact that the health professions, for one poor reason or another, sometimes cut off the corners where safety standards are concerned. The self-opinionated health worker is one obstacle; why, he reflects, should I not use hypochlorite which has served me well all my life? Greed is a recurrent motive; how many cents a day shall we save if we use a disposable again? Add to such things a large measure of indifference, the smug belief that one is immune from discovery, and the eternal human belief that accidents are things which happen to other people, and you have a well-tested recipe for tragedy. Thanks to people like good Professor Policarpo, Argentina is at least being made aware of its problem. How many places in the world have yet to get that far?

\section{References}

1 W.H.O. (1987) Sterilization Alert. Expanded Programme on Immunization in Developing Countries. World Health Organization, Geneva.

2 Mann $\mathrm{J}$ et al. Risk factors for human immunodeficiency virus seropositivity among children 1-24 months old in Kinshasa, Zaire. Lancet 1986; September 20th:654-656.

3 Quinn T et al. AIDS in Africa: an epidemiological Paradigm. Science 1986;234:955-963.

4 C.D.C. (1968) Recommendations for preventing transmission of human T-lymphotropic virus type III/lymphadenopathy associated virus during invasive procedures. Ann. Intern. Med. 1968;104:824825.

5 Suwangoon P. (1988) The cost comparison and sterility of reusable and disposable syringes and needles at Chulalongkorn Hospital. J Med Assoc Thail 1988; July: 11-13.

6 Mann J et al. HIV Seroprevalence among hospital workers in Kinshasa, Zaire; lack of association with occupational exposure. JAMA, 256: 3009-3102.

7 Alacena V. AIDS in Third World Countries. N.Y. State J. Med. 1986;86:446.

8 Ministry of Health of Argentina VIH: El virus de la immunodeficiencia humana; normas the bioseguridad. Buenos Aires, 1988.

9 Manrique LA, Gonzalez OF, Parrili O. Representatives: Preamble to the Public Health Bill, Argentina. Cited by Policarpo L., private communication.

10 Policarpo L. Petition to the Ministry of Health of Argentina, Nr. 1259/91-1, 1991.

11 Anon. Allonaron un sanitario por mal uso de jeringas. La Prensa (Buenos Aires), 12 November, 1988. 